\title{
Urgensi Pendidikan Anak Usia Dini Dalam Perspektif Hadits di Masa Pandemi Coronavirus
}

\author{
Afifah Fatihakun Ni'mah Wahidah ${ }^{1}$, Muhammad Alfatih Suryadilaga ${ }^{2}$ \\ ${ }^{1,2}$ UIN Sunan Kalijaga Yogyakarta, Yogyakarta, Indonesia
}

DOI : https://doi.org/10.15642/jeced.v3i1.601

\begin{abstract}
Urgency Parents have an important role for Early Childhood Education especially with the covid outbreak so that children have to learn from home. This article aims to examine the urgency of Early Childhood Education education in the perspective of hadith, especially the hadith on the obligations of parents in educating children, which is associated with conditions in the era of the Coronavirus pandemi. Family is the first and foremost education for a person. Education in the family plays a role in developing character, personality, cultural values, religious and moral values, and simple skills. There is a physical distancing policy so that learning is carried out online (in a network) so that the role of parents is very urgent in ensuring the continuity of their children's education. is the responsibility of the parents; Second, the best gift parents give their children is a good education; Third, parents as the first and foremost madrasa, especially for early childhood, are responsible for their children's education.
\end{abstract}

\section{Article Info}

Article history:

Received: June 08, 2020

Approved: June 30, 2021

Published online: June 30, 2021

\section{Keywords:}

the urgency of AUD education,

hadith perspectives,

Coronavirus pandemi

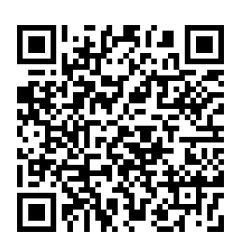

Informasi Artikel

Diterima: 08062020

Disetujui: 30062021

Publikasi online: 30062021

\section{Kata kunci:}

urgensi pendidikan AUD,

perspektif hadis,

pandemi Coronavirus watak, kepribadian, nilai-nilai budaya, nilai-nilai keagamaan dan moral, serta keterampilan sederhana. Adanya kebijkana phisical distancing sehingga pembelajaran dilaksanakan daring (dalam jaringan) sehingga peran orang tua sangat urgen dalam menjamin keberlangsungan pendidikan anak-anaknya. Urgensi pendidikan AUD dalam perspektif hadist: Pertama, Orangtua selaku pemimpin harus memimpin anggota keluarganya/anaknya karena pembentukan akhlak anak merupakan tanggungjawab orangtuanya; Kedua, Pemberian terbaik orangtua kapada anaknya adalah pendidikan yang baik; Ketiga, orang tua sebagai madrasah pertama dan utama khususnya bagi anak usia dini bertanggungjawab terhadap pendidikan anaknya. 


\section{PENDAHULUAN}

Orang tua pastinya menginginkan anak-anaknya dapat berkembang secara maksimal, baik dari segi kognitif, sosial, maupun emosinya. Guna terciptanya generasi muda penerus bangsa yang berkompeten, sehingga orang tua harus mendidik anaknya sebaik mungkin dan memberikan pendidikan sejak dini dengan semaksimal mungkin. Pendidikan keluarga, merupakan salah satu pendidikan yang harus diperhatikan, karena keluarga merupakan kesatuan kemasyarakatan yang paling kecil. Kelompok ini sering juga disebut dengan keluarga inti. (Joesoef, 1992, pp. 73-75). Dengan demikian jelaslah bahwa lingkungan keluarga merupakan lingkungan pendidikan yang pertama dalam membentuk pribadi anak didik. Latihan secara fisik, mental, sosial dan bahasa serta keterampilan dalam lingkungan ini harus mulai dibina sedini mungkin. Anak-anak juga mulai diperkenalkan dengan tata krama kehidupan dalam keluarga dan masyarakat dalam waktu yang bersamaan, dan mereka juga bergaul dengan teman sebayanya.

Artikel ini menjelaskan tentang peninjauan beberapa hadits kewajiban orang tua dalam mendidik anak, yang dikaitkan dengan kondisi di era pandemi Coronavirus. Selanjutnya dijelaskan bagaimana peran orang tua di era pandemi Coronavirus dalam pembelajaran anak. Selain itu menjelaskan tentang faktor apa yang menjadikan pembelajaran dilakukan di rumah pada era pandemi Coronavirus dan bagaimana transformasi (perubahan) pembelajaran dalam konteks pembelajaran selanjutnya di dunia maya/sosial media. Ketiga masalah tersebut akan dikaji dalam artikel ini dengan melihat berbagai fenomena yang terjadi dalam masyakarat sekarang ini. Terkhusus lagi dalam bidang pendidikan dan segala yang berkaitan dengan bidang pendidikan lainnya, yaitu para pendidik ataupun orang tua yang terkena dampak dari pandemi Coronavirus ini.

Meletakkan dasar bagi pendidikan akhlak dan pandangan hidup keagamaan pada anak merupakan tugas utama dari keluarga. Anggota keluarga yang lain turut andil dalam pemberian pengaruh pada sifat dan akhlak anak. Mengenai hubungan pendidikan dalam keluarga adalah didasarkan atas adanya hubungan antara orang tua dan anak. Pendidikan dalam keluarga dilaksanakan atas dasar rasa cinta, rasa kasih sayang yang murni, rasa cinta kasih sayang inilah yang menjadi sumber kekuatan yang tak kunjung padam pada orang tua untuk memberikan bimbingan dan pertolongan yang dibutuhkan oleh anak (Kusuma, 1973, pp. 109-110). Namun bukan berarti pada saat di era pandemi Coronavirus seperti ini perkembangan anak khususnya sosial anak tidak bisa dikembangkan, awalnya anak-anak bisa bertemu dengan teman-temannya di sekolah bermain bersama, saat ini mereka dianjurkan di rumah dahulu hingga keadaan aman. Karena untuk mengembangkan sosial anak tidak hanya dapat dikembangkan dengan interaksi anak dengan teman sebayanya, tetapi juga dapat dikembangkan dengan salah satunya melakukan kegiatan yang mengandung suatu kerjasama bisa dilakukan anak bersama orang tua tentunya.

Dalam kehidupan keluarga bentuk kerjasama dapat dicontohkan saat anak-anak yang membantu menolong anggota keluarga yang lain seperti menolong saudaranya yang membutuhkan bantuan, membantu ibu menyapu lantai, membantu ayah meyiram tanaman dan berbagai macam kegiatan lainnya, semuanya dapat memberi pendidikan pada anak terutama memupuk berkembangnya suatu kesadaran sosial pada anak (Mulyani, 2013, pp. 07-11). Dengan begitu masa pandemik Coronavirus sekarang ini tidak akan mengganggu perkembangan sosial anak, interaksi anak dengan orang tua mereka akan lebih sering karena orang tua akan lebih banyak dirumah. Sehingga sangat besar sekali dampak positifnya jika masa pandemi ini benarbenar dimanfaatkan oleh orang tua untuk semakin menjalin kedekatan orang tua dengan anak yang lebih baik.

Adanya wabah Coronavirus di Indonesia ini membuat para orang tua khawatir apabila anaknya atau anggota keluarganya terinfeksi virus ini. Hal ini menjadi penting bagi orang tua untuk mengupayakan agar anak-anak dan anggota keluarga lainnya tidak tertular virus ini dari orang lain. Selain berdoa kepada Allah SWT, orang tua juga melatih anak tentang hidup bersih 
dan sehat, menjaga kebersihan diri dan membersihkan rumah, makan makanan yang bergizi seperti buah dan sayuran, sering mencuci tangan menggunakan sabun dengan tehnik cuci tangan yang benar, membuang sampah pada tempatnya, selalu menjaga kebersihan dimanapun berada baik di dalam rumah maupun di luar rumah, membatasi kegiatan di luar rumah bisa menjadi upaya orang tua untuk mencegah anak tertular virus corana. Orang tua bisa membuat kegiatan atau permainan yang bersifat edukasi, sehingga anak tidak merasa bosan di rumah. Dalam hal ini kebersihan tidak hanya terwujud melalui kebersihan lahir, yakni menjaga kebersihan diri dan lingkungan sekitarnya. Tetapi juga terwujud melalui kebersihan batin, yakni dengan bersihnya hati dan sifat-sifat tidak terpuji (Cahyono, 2017, p. 56).

\section{METODE}

Kajian dalam artikel ini merupakan data-data kualitatif yang diambil dari beragam data dokumen dan pengamatan mendalam. Kehadiran data lewat pengamatan mendalam penting dalam menjadikan kualitas data menjadi baik. Untuk melengkapi data obeservasi dengan melihat fakta dalam proses pembelajaran yang dialami oleh siswa dan siswi PIAUD dan dilakukan oleh beragam guru juga dilakukan wawancara atas beragam key person untuk menjadikan kajian lebih menarik dan mendalam yakni yang menjadi pengajar di PIAUD dan ketua pengelolanya. Selain itu, data diperoleh melalui dokumen yang ada dalam pembelajaran di dalamnya dengan melihat dokumen RPM da RPPH yang dibuat guru. Dengan demikian, data dalam artikel ini merujuk beragam data yang memungkinkan kualitas data lebih baik dengan melibatkan beberapa pihak.

Data hadis dalam kajian ini merujuk pada kajian sebagaimana yang lazim dilakukan ulama hadis. kitab-kitab yang digunakan acuan referensi merupakan kitab yang mu'tabarah yaitu kitab dalam Kutub al-Sittah yang merupakan hirarkhi kitab yang paling baik dalam tradisi Sunni. Setidaknya kesahihan ditunjukkan melalui Kitab Sahih Bukhari dan Sahih Muslim (Elewa, 2019, pp. 261-76). Hadis dalam kitab tersebut kemudian dicari model pemahamannya lewat kitab syarah penjelasan di dalamnya yakni tentang PIAUD (Sulaemang, 2016, p. 125). Model kitab syarah merupakan bagian terpenting dalam perjalanan pemahaman yang telah dilakukan oleh Nabi saw. berikut generasi berikutnya sampai ulama abad ke-7 Hijriyah. (Yahya, 2014, p. 365).

Model ini kemudian dikembangkan kontekstualisasikan dalam konteks PIAUD. PIAUD sebagai bagian obyek pendidikan yag spesifik memiliki pemahaman yang spesifik sesuai dengan kapasitas umur mereka (Filasofa, 2017, p. 111). Atas dasar inilah kajian hadis dalam PIAUD menjadi penting untuk dilakukan. Kajian ini akan menghasilkan kajian spesifik yang baru di banding kajian yang sudah ada yakni kajian hadis di pesantren, kajian hadis di madrasah, kajian hadis di Perguruan Tinggi atau kajian khas Hadis di Indonesia lainnya.

\section{HASIL PENELITIAN DAN ANALISIS}

\section{Peran orang tua di era pandemi Coronavirus dalam pendidikan anak}

Wabah Coronavirus Disease 2019 (COVID-19) telah mewabah ke berbagai negara, termasuk Indonesia. Sehingga sekarang virus corona berstatus pandemi, dan dampak dari ini semua adalah salah satunya terhadap sistem pendidikan. Istilah pandemi sendiri dikenal dalam dunia epidemiologi atau ilmu yang mempelajari pola penyebaran penyakit. Dalam kamus epidemiologi, wabah menjadi bagian paling kecil dalam penularan penyakit. Pandemi merupakan epidemi yang menyebar ke beberapa negara atau benua dan memengaruhi masyarakat dalam jumlah besar, yang diungkapkan oleh Center for Disease Control and Prevention (CDC) Amerika Serikat. Ada tiga kriteria umum sebuah penyakit dikatakan sebagai pandemi. Pertama, virus dapat menyebabkan penyakit atau kematian. Kedua, penularan virus dari orang ke orang terus berlanjut tak terkontrol. Ketiga, virus telah menyebar ke hampir seluruh dunia. Kriteria tersebut masih bersifat umum, dan hingga saat ini belum ada kriteria 
spesifik yang menentukan status pandemi. Pandemi juga tidak ditentukan oleh jumlah kasus atau kematian yang diakibatkan (Tim CNN Indonesia, 2020 12:29).

Akibat dari ditetapkannya wabah ini sebagai pandemi, maka pemerintah membuat kebijakan yang mengaharuskan anak-anak untuk melakukan kegiatan belajar di rumah, sehingga peran orang tua pada proses pembelajaran dirumah sangat dibutuhkan. Mungkin dulu masih ada orang tua yang acuh terhadap bagaimana proses belajar anaknya ketika sekolah, bagaimana sikap dan respon anak ketika pembelajaran berlangsung di kelas. Diharapkan dengan pembelajaran yang dilakukan di rumah ini secara tidak langsung akan mengajarkan kepada orang tua bagaimana menjadi seorang guru. Dimana orang tua harus bisa memastikan anaknya tetap belajar pada masa waspada virus Corona ini, bukan malah menganggap proses pembelajaran libur, atau malah mengajak anaknya jalan-jalan. Disinilah orang tua harus mampu menggerakan semangat belajar anak ketika dirumah, dan makin lebih peduli lagi terhadap pendidikan anaknya. Sebagaimana sesuai dengan hadits Rasulullah shallallahu 'alaihi wa sallam, sesungguhnya kedua orang tualah yang bertanggungjawab penuh memikulkan pendidikan anak. Dari Ibnu radhiallahu 'anhu, bahwa dia berkata, Rasulullah shallallahu 'alaihi wa sallam bersabda, (Indriyati , 2011, p. 175).

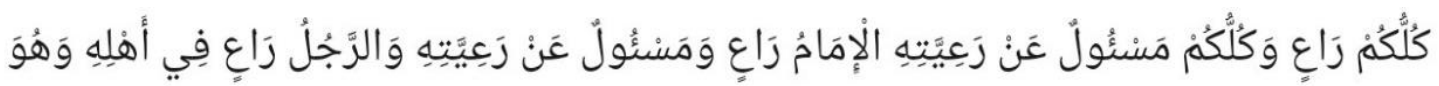

$$
\begin{aligned}
& \text { مَسْسُُولْ عَنْ رَعِيَّتِنِهِ }
\end{aligned}
$$

"Setiap kalian adalah pemimpin dan akan dimintai pertanggungjawaban atas kepemimpinannya. Seorang imam adalah pemimpin dan akan dimintai pertanggunjawabannya dan demikian juga seorang pria adalah seorang pemimpin bagi keluarganya dan akan dimintai pertanggungjawaban atas kepemimpinannya." (HR. Bukhari: 2278).

Dalam situasi pandemi Coronavirus menjadikan pembelajaran yang awalnya anak terima di sekolah sekarang harus dilakukan di rumah. Disinilah orang tua wajib dan bertanggung jawab penuh terhadap pendidikan anak langsung, dan para pendidik yang mendidik anak di sekolahsekolah, sekarang hanyalah menjadi partner bagi orang tua dalam proses pendidikan anak. Orang tualah yang harus berusaha keras mendidik anaknya khusunya dalam bidang akademik dan yang paling penting adalah pendidikan spritualnya (agama) anak. Sehingga pendidikan yang diberikan orang tua tersebut merupakan pemberian yang berharga bagi sang anak, meski terkadang hal itu jarang disadari. Dalam sebuah hadits yang diriwayatkan Al-Hakim, Nabi shallallahu 'alaihi wa sallam bersabda, (Muslim, Maret 2014).

$$
\text { ما نحل و الد ولده أفضل من أدب حسن }
$$

"Tiada suatu pemberian yang lebih utama dari orang tua kepada anaknya selain pendidikan yang baik." (HR. Al Hakim: 7679).

Hadits diatas menjadi salah satu dasar bagi orang tua bahwa pendidikan anak menjadi sesuatu yang sangat wajib diperhatikan, karena pendidikan yang baik akan yang didapatkan anak dari orang tua akan menjadikan kehidupan anak nantinya menjadi baik pula. Orang tua harus memberikan contoh dan teladan yang patut, sehingga anak akan menganggap bahwa orang tuanyalah yang wajib dia contoh. Terpenting lagi pendidikan yang baik tersebut harus dimulai dari usia dini, karena pada masa usia dini merupakan dasar untuk membentuk dasar-dasar kepribadian dan kekuatan spiritual untuk bekal anak dewasa nanti. Disamping itu, dalam 
melakukan pendidikan kepada sang anak, orang tua hendaknya menggunakan metode pembiasaan. (Ulwan, 2001, p. 200).

Maksudnya anak dilatih untuk berakhlak yang baik dan bertingkah laku yang sopan khususnya kepada orang tua dan membentuk kebiasaan yang baik dalam kesehariannya. Contohnya di sekolah anak-anak diajaran untuk pembiasaan menjaga kebersihan diri dan lingkungannya, untuk pembelajaran di rumah ini orang tua bisa lebih memasukkan pembasaan tersebut dengan praktek langsung kepada anak, misalnya pada masa pandemi Coronavirus ini anak diajak untuk lebih memperhatikan kebersihan badan, tangan, bahkan lingkungan di dalam maupun di luar rumah. Pembiasaan yang dilakukan oleh orang tua tidak hanya pada saat ada wabah Coronavirus. Orang tua membiasakan anak untuk selalu menjaga kebersihan disetiap harinya. Hal ini penting bagi kehidupan anak di masa yang akan datang. Setelah anak dewasa anak akan terbiasa untuk selalu menjaga kebersihan baik dirinya maupun di lingkungan sekitarnya. Anak tidak akan mudah tertular atau terinfeksi penyakit menular yang disebabkan oleh virus atau bakteri. Nantinya saat dewasa akan tercipta sebuah paradigma dalam diri anak bahwa sangat penting untuk menjaga kebersihan lingkungan dan akan merasa risih melihat sesuatu yang kotor (Anggi, 2018, p. 30).

\section{Faktor apa yang menjadikan pembelajaran dilakukan di rumah di era pandemi Coronavirus}

Dalam rangka melakukan pencegahan pandemi Coronavirus, pemerintah menginstruksikan untuk menerapkan Social Distaning (pembatasan bersosialisasi dengan orang lain), bahkan dengan semakin menyebarnya wabah Coronavirus yang sangat cepat ke berbagai dearah Indonesia Phisical Distancing (pembatasan kontak langsung dengan orang) diterapkan. Dan sekarang sudah banyak daerah yang melakukan Lockdown (penutupan daerah) karena situasi yang mendesak yang harus dijalankan untuk meredam persebaran Coronavirus, dan itu terbukti efektif di berbagai negara. Sebetulnya, jauh sebelum masyarakat modern mengenal istilah Lockdown, Nabi saw sudah ajarkan solusi tersebut, Nabi saw bersabda :

$$
\text { إذا سمعتم بالطاعون بأرض فلا تقدموا عليه و إذا وقع بأرض و أنتم بها فلا تخرجو ا فرار ا منه }
$$

Artinya: "bila kalian mendengar penyakit (menular) Tha'un di sebuah tempat, maka janganlah mendatangi tempat itu. Dan jika penyakit itu terjadi di tempat sementara kalian berada di dalamnya (tempat penyakit itu) maka janganlah kalian lari (keluar) darinya." (HR. Bukhari dan Muslim dari Abu Hurairah)

Saat ini dibutuhkan langkah yang cepat dan tepat agar tidak memakan banyak korban lagi di Negeri kita tercinta. Ini semua bukan bentuk ketakutan apalagi minim tawakkal atau lemah Iman, lebih tepatnya syariat mengajarkan kita untuk mengaitkan sebab dengan akibat (Robthul Asbaab bil Musabbabaat), inilah yang dinamakan ikhtiar (Alathas, 2020, 14:18). Oleh sebab itu, berbagai lembaga pendidikan mulai dari jenjang TK, SD, SMP, SMA, bahkan Univertas juga menutup kegiatan pembelajaran di sekolah dan sebagai gantinya yaitu dengan menerapkan sistem Daring (dalam jaringan) pembelajaran online yang dilakukan di rumah masing-masing. Pada jenjang anak usia dini, mereka memiliki sifat keingintahuan yang tinggi. Anak-anak akan bertanya hal-hal yang baru ia lihat atau rasakan, dan akan terus bertanya hingga anak mendapat jawabannya. Maka dari itu tidak heran, apabila anak sering menanyakan alasan kenapa anak harus belajar di rumah dalam waktu yang lama. Timbul pertanyaan dari si anak kenapa dia 
belajar di sekolah, kenapa dia harus belajar di rumah bersama ayah dan ibunya. Dan masih banyak pertanyaan-pertanyaan yang muncul di pikiran si anak (Mulyasa, 2014, p. 76). Sehingga orang tua dan pendidik harus bekerjasama dengan baik. Para pendidik harus menentukan metode apa yang cocok untuk digunakan agar pembelajaran yang dilakukan di rumah dapat berjalan dengan lancar dan hasilnyapun sesuai dengan harapan bersama. Namun para pendidik juga tidak boleh melepas begitu saja anak-anak atau memebebaskan anak-anak, pendidik harus juga melakukan pengawasan secara bertahap. Semua itu tidak lepas dari bantuan sang orang tua anak itu sendiri, dengan begitu tugas yang awalnya pendidik di sekolah lakukan, menjadi tugas orang tua untuk membimbing sang anak dalam pendidikannya. Pendidik/guru hanya sebagai patner orang tua untuk memperlancar proses kegiatan belajar disekolah, dan orang tua secara tidak langsung menjadi seorang guru untuk anak-anaknya.

Namun, berbagai hal pun muncul ketika pembelajaran dilaksanakan dengan cara daring/belajar di rumah, dari masalah kurangnya sarana seperti smartphone dari anak/siswa, hingga gagap akan teknologi (gaptek) yang dialami bukan hanya siswa atau pun orang tuanya, tetapi juga guru. Ketika pembelajaran tersebut diterapkan oleh sekolah, salah satu yang menjadi kewajiban adalah sarana seperti handphone yang mungkin tidak semua orang tua mempunyai, apalagi di desa-desa. Namun, berbagai langkah pun dilakukan demi mempermudah jalannya proses pembelajaran tersebut, salah satunya kebaikan teman atau tetangga yang meminjamkan handphonenya demi mempermudah proses kegiatan belajar di rumah. Sebenarnya bukan hal itu yang menjadi salah satu hikmah utama dari pemberlakuan belajar di rumah ini, namun bagaimana orang tua mampu berperan sebagaimana guru di kelas ketika pelaksanaannya, orang tua harus pandai-pandai membuat anaknya menjadi semangat belajar di rumah, yang mungkin mereka biasanya belajar bersama-sama dengan temannya di sekolah sekarang harus belajar sendiri di rumah dengan orang tuanya saja (Wahyudi, 2020, p. 98).

\section{Bagaimana transformasi (perubahan) pendidikan dalam konteks pembelajaran di dunia maya/sosial media.}

Secara tidak langsung, karena adanya pembelajaran model pembelajaran (daring) di rumah ini dikarenakan keadaan. Namun, sesungguhnya adanya proses belajar di rumah membuat anak lebih mengurangi aktifitas bermainnya ketika mereka memegang handphone, mulai dari bermain game, hingga bermedia sosial. Anak atau siswa akan lebih disibukan dengan adanya tugas yang datang dari guru mereka ketika ada notifikasi masuk melalui Whatsapp atau aplikasi yang menjadi sarana komunikasi pembelajaran. Sehingga akan membuat guru akan lebih aktif dalam memberikan soal melalui media elektronik/daring, sehingga wacana kelas digital akan perlahan dapat diterapkan dan baik siswa maupun guru akan mulai terbiasa. Meski akan lebih mempermudah, pastinya kekurangan dan kelebihan akan ada dari setiap proses pembelajaran, dimana kejujuran dari siswa dan inovasi serta teknis dari proses belajar di rumah menjadi tugas tambahan bagi guru. Guru akan menjadi berpikir lebih bagaimana cara menyampaikan pengetahuan kepada siswa, serta seperti apa dalam membangun karakter siswa melalui pembelajaran daring tersebut. Salah satunya adalah menguji kejujuran siswa dalam mengerjakan tugas, dan bagaimana cara siswa dalam mengerjakannya.

Disini peran orang tua yang harus membantu proses belajar di rumah agar berlangsung dengan efektif dan penuh dengan integritas. Kalimat ini bukan bermaksud menuduh adanya ketidakjujuran pada siswa, namun segala kelemahan harus diantisipasi dan ditanggulangi, dan itu tugas guru, serta kerjasama dari wali siswa/orang tua. Tugas-tugas dari guru yang harus disampaiakan lewat media yang mendukung, secara tidak langsung membuat para guru harus 
mencari aplikasi yang mendukung pula, yang sekaligus bisa memantau anak-anak didiknya dalam pelaksanaannya. Mulai dari aplikasi yang menggunakan video/memunculkan wajah dari peserta didiknya hingga guru sendiri yang membuat video pembelajaran kemudian dikirim melalui aplikasi WhatsApp atau yang sejenisnya, sehingga anak paham dengan materi yang disampaikan oleh gurunya, ini sangat efektif untuk proses pembelajaran yang dilakukan dirumah sehingga guru dapat langsung memberikan pengawasan dan penilaian seara sekaligus.

Para pendidik dan orang tua harus memahami keterampilan-keterampilan yang dibutuhkan untuk pengembangan diri peserta didik, misalnya masa belajar di rumah ini peserta didik diarahkan untuk mencari pemecahan masalah yang berhubungan dengan wabah Coronavirus, dan solusinya bisa dari sisi kesehatan, pangan, sosial, ekonomi dan lain sebagainya. Solusi yang ditawarkan harus memiliki lanadasan yang kuat, dan peserta didik akan belajar mencari tahu dan kemudian harus di presentasikan dalam bentuk vidio dan di unggah ke media sosial seperti Youtube, Facebook, Line, WhatsApp ataupun yang lainnya. Dengan berbagai manfaatnya sehingga dapat mengurangi tingkat tekanan para orang tua di rumah, menghilangkan kegagapan pendidik dalam pelaksanaan pemebelajaran dirumah, dan yang pasti mengembalikan dunia pendidikan ke arah yang seharusnya dituju. Sehingga akan memunculkan berbagai inovasi generasi penerus bangsa yang selama ini tidak diberi kesempatan karena waktu belajarnya habis untuk diberi tahu belajar apa, dan konsep ini akan mengubah pandangan orang tua dan pendidik yangs selama ini melihat handphone dan perangkatnya hanya sebagai konsumsi semata, sekarang akan berubah mejadi alat produksi. Inilah proses yang diharapkan untuk membangun karakter sang peserta didik yang unggul.

\section{PEMBAHASAN}

Pendidikan telah menjadi bagian dari kebutuhan manusia, pendidikan memiliki peranan yang sangat penting untuk menciptakan generasi yang unggul. Peradaban dikatakan maju atau tidak ditentukan oleh baik tidaknya mutu dari pendidikan yang ada pada waktu itu. Demi mewujudkan tujuan pendidikan, sehingga perlu adanya upaya secara terus menerus dan terarah. Pendidikan yang dilakukan dalam lingkungan keluarga menjadi tanggung jawab orang tua, di sekolah menjadi tanggung jawab guru, dan di masyarakat yang menjadi tanggung jawab masyarakat dan pemimpin masyarakat. Dari ketiga lembaga tersebut haruslah berjalan berdampingan dan terarah, seiring, sejalan dan setujuan serta harus saling melengkapi antara yang satu dengan yang lainnya. Dengan adanya masa pandemi Coronavirus sekarang ini membuat peran guru di sekolah sedikit bekurang, karena guru hanya mengamati anak-anak, orangutualah yang berperan penuh dalam mengawal, mendampingi, dan mengawasi dari proses pembelajaran sang anak.

Fungsi pendidikan salah satunya adalah memanusiakan manusia dalam rangka mewujudkan budaya, mengembangkan segala potensi bawaan (potensi fitrah) yang ada pada individu supaya dapat dipraktekkan olehnya sendiri, dan masyarakat untuk menghadapi tantangan-tantangan tatanan masyarakat dan lingkungan yang selalu berubah. Namun pada sisi lain, belakangan ini ternyata praktek pendidikan yang dilakukan dalam dunia pendidikan islam khususnya masih jauh dari apa yang menjadi harapannya. Dapat dilihat dari realita dunia pendidikan islam di Indonesia, pendidikan islam di Indonesia dilanda krisis multi dimensi, hal tersebut dapat diukur dari rendahnya kualitas Sumber Daya Manusia dan kurang optimalnya potensi SDM yang diperdayakan, membuat kondisi umat Islam mengalami penurunan di segala aspek kehidupan. Orang tua memiliki peran yang sangat penting terhadap pola perkembangan anaknya. Baik buruk pendidikan seorang anak ditentukan oleh pendidikan yang diberikan oleh orang tuanya. Karena orang tualah peran yang sangat penting dalam membentuk jati diri anak (Sidiq, 2011, p. 255). Demi mewujudkan tujuan pendidikan agama yang membentuk manusia baik dalam segi jasmani maupun rohani, intelektuan maupun spiritual (Putra, Konsep 2016, p. 
42). Diharapkan di masa pandemi Coronavirus ini orang tua yang memegang peran utama pendidikan anak harus mampu memberi bekal pendidikan agama yang cukup, seperti mengajari anak-anak sholat, puasa, sedekah dan segala kegiatan keagamaan lainnya yang akan sangat berguna demi kelangsungan kehidupan anak-anak selanjutnya.

Dalam pendidikan keluarga, orang tua sebagai pelaksana lapangan yang terjun langsung untuk mendidik anak-anaknya. Seluruh tenaga, pikiran, dan kemampuan finansial akan Orang tua curahkan untuk mencetak anak yang sesuai dengan keinginannya. Pendidikan agama yang saharusnya memang sudah diberikan oleh kedua orang tuanya sejak anak usia dini (Mahdi 2015, p. 191). Fungsi pendidikan keluarga yang terpenting adalah: Pertama, pengalaman pertama masa kanak-kanak. Dalam pendidikan keluarga, anak memperoleh pengalaman pertama yang merupakan faktor penting dalam perkembangan pribadi anak. Kedua, menjamin kehidupan emosional anak. Dalam pendidikan keluarga kehidupan emosional atau kebutuhan rasa kasih sayang anak dapat terjamin dengan baik. Hal ini disebabkan karena adanya hubungan darah antara pendidik dan anak didik. Terjaminnya kehidupan emosional anak pada waktu kecil berarti menjamin pembentukan pribadi anak selanjutnya. Ketiga, menanamkan dasar pendidikan moral. Dalam pendidikan keluarga, maka pendidikan ini selanjutnya menyentuh pendidikan moral anakanak karena di dalam keluargalah terutama tertanam dasar-dasar pendidikan moral melalui contoh-contoh yang nyata dalam perbuatan dan kegiatan hidup sehari sehari. Keempat, Memberikan dasar pendidikan kesosialan. Kelima, dalam pendidikan keluarga penting sekali untuk meletakkan dasar pendidikan agama bagi anak, karena pendidikan agama yang diberikan dengan baik akan tercermin dalam kehidupan anak (Suparno dan Setiawati, 2010, p. 23).

Di dalam keluarga inilah tempat meletakkan dasar-dasar kepribadian anak usi dini, karena pada usia ini anak lebih peka terhadap pengaruh dari pendidikannya. Sesuai dengan sabda Nabi:

$$
\text { كل مولود يولد على الفطرة و إنما أبو اه يمجسانه أويهو دانه أو ينصر انه }
$$

"Setiap anak yang lahir dilahirkan diatas fitrah hingga ia fasih (berbicara), maka kedua orang tuanya lah yang manjadikannya Yahudi, Nasrani atau Majusi." (HR. Al-Baihaqi dan AthThabarani dalam al-Mu'jamul Kabir).

Hadits nabi tersebut memberikan suatu kebebasan kepada kita untuk membentuk anak didik sesuai dengan keinginan kita, dengan prinsip tidak bertentangan dengan nilai-nilai Islami. Dalam hal ini pendidikan dalam keluarga merupakan tanggung jawab kita bersama selaku makhluk sosial dan makhluk pendidikan untuk membentuk anak didik yang memiliki kecakapan intelektual, kepribadian yang baik, keterampilan dan akhlakul karimah yang tinggi yang mencerminkan nilai-nilai Islami. Berhasil tidaknya pendidikan dalam upaya membentuk karakteristik anak didik dalam keluarga tergantung pada usaha yang keras disertai dengan ketekunan dan kesungguhan disertai dengan doa kepada Allah SWT selaku dzat yang menentukan segalanya (Harun, 2016, p. 90). Reymond. W. Murray mengemukakan fungsi keluarga adalah sebagai berikut: 1) kesatuan turunan (biologis) dan juga kebahagian masyarakat, 2) kewajiban dalam meletakkan dasar pendidikan, rasa keagamaan, kemauan, rasa kesukaan kepada keindahan, kecakapan berekonomi, dan pengetahuan penjagaan diri pada si anak (Joesoef, 1992, pp. 73-75).

Belajar merupakan kegiatan untuk memperoleh ilmu pengetahuan. Macam-macam cara belajar yang dapat dilakukan, baik dengan membaca, mendengar, melihat dan merasa. Semua aktifitas ini dilakukan seseorang dalam rangka belajar (Umar, 2015, p. 55). Dengan diketahui betapa pentingnya pemberian pendidikan kepada anak-anak, dengan adanya pandemi Coronavirus ini harusnya tidak menurunkan semangat para orang tua dalam memberikan pendidikan kepada anak. Pendidikan tidak hanya diberikan di sekolah namun pendidikan juga bisa diberikan dimana saja, termasuk pada lingkungan yang terdekat oleh anak yaitu keluarga. Sadar atau tidak pada masa pandemi corovirus ini anak-anak dan orang tua bisa sama-sama belajar, anak-anak belajar untuk mengembangkan segala kemampuannya dan orang tua belajar 
bagaimana memberikan pendidikan yang baik untuk anaknya. Namun banyak dari orang tua yang merasa belum siap untuk memberikan pendidikan untuk anaknya, dikarenakan orang tua yang dari awal telah mempercayakan pendidikan anaknya pada suatu lembaga pendidikan. Sehingga pada saat situasi seperti ini orang tua belum siap dalam hal metode atau cara-cara yang tepat, efektif dan efisien yang akan diberikan kepada anaknya.

Islam telah mengajarkan berbagai metode atau cara yang dapat dipraktekkan oleh para orang tua dalam memberikan pendidikan kepada anaknya dirumah. Yaitu dengan pendidikan dengan kasih sayang, pendidikan dengan keteladanan, pendidikan dengan nasihat, pendidikan dengan pembiasaan, pendidikan dnegan cerita, dan pemberian hadiah dan hukuman. Selain itu orang tua bisa berperan sebagai patner bagi anak-anaknya, dengan cara menghargai hasil kerja dan hasil karya mereka, memebrukan rasa nyaman dan nyaman jika berada disampingnya, menunjukkan perhatian, meluagkan waktu khusu untuk merka, menjaga kekompakan dan lain sebagainya. Karena keluargalah lingkungan pendidikan dasar yang cukup efektif dan efisien dalam upaya mengantarkan generasi penerus dalam membekali kemampuan diri sang anak dengan sebaik-baiknya sehingga dapat menjadi generasi yang handal, terampil, tangguh serta berkarakter baik di mata manusia terlebih di mata Allah S.W.T.

Anak adalah karunia Allah SWT yang harus disyukuri dengan cara mengasuhnya dengan sebaik-baiknya sesuai dengan aturan Islam, sehingga anak akan menjadi investasi dunia dan akhirat bagi orang tuanya. Karena mereka adalah pemimpin di muka bumi, wakil Allah di bumi harus memiliki karakter yang beriman dan bertaqwa. Pada dasarnya dalam keluargalah anak berkembang, oleh karena itu keluarga menduduki tempat terpenting bagi terbentuknya pribadi anak secara keseluruhan yang akan dibawa sepanjang hidupnya. Sedangkan lembaga-lembaga lain di masyarakat adalah sekedar membantu, melanjutkan, memperbanyak apa yang telah diperoleh dari keluarga. Peran orang tua dalam mendidik anak dimulai dari buaian sampai liang lahat dan sudah menjadi kewajiban bagi setiap manusia untuk mendidik anaknya kearah yang lebih baik (Zulfitria, 2017, p. 38).

Anak-anak di bentuk dan di didik sejak dari awal, Islam telah menekankan pembentukan dasar (ketauhidan) seorang anak bukan hanya kelakuan fisik dan intelektualnya saja, tetapi pemantapan akhlak perlu diterapkan seiring dengan penerapan keimanan di dalam ruh dan jiwa anak. Kalau informasi yang diterima oleh seorang anak hanya diatas pengetahuan tanpa adanya penanaman aqidah dan pemantapan akhlak akibatnya generasi yang dihasilkan mungkin bijaksana dan tinggi tahap perkembangan intelektualnya tetapi dari aspek-aspek yang lain (aqidah dan akhlaknya) kurang. Sehingga peran orang tua dalam Islam harus bertanggung jawab dalam memberikan pendidikan sesuai dengan fitrahnya, yaitu keimanan kepada Allah Swt. Fitrah merupakan kerangka dasar operasional terhadap proses penciptaan manusia, didalamnya terkandung kekuatan potensial untuk tumbuh dan berkembang secara maksimal dan mengarahkannya untuk mencapai tujuan penciptaannya (Kusuma, 1973, p. 109-110).

Konsep dasar keimanan ini telah digambarkan dalam Al-Qur'an ketika Luqmanul Hakim memberikan pendidikan dasar terhadap anaknya. Anak merupakan amanah dari Allah Swt yang diberikan kepada setiap orang tua, karena anak adalah buah hati serta tumpuan harapan serta kebanggaan keluarga. Anak adalah generasi mendatang yang mewarnai masa kini dan diharapkan dapat membawa kemajuan dimasa mendatang. Anak juga merupakan ujian bagi setiap orang tua sebagaimana disebutkan dalam Al-Qur'an surah al-Anfal ayat 28 yang berbunyi:

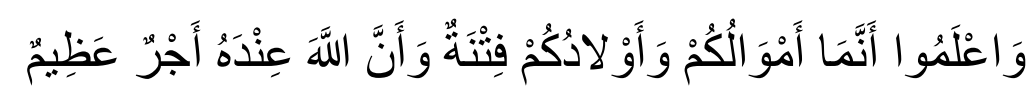

Artinya: "Dan ketahuilah bahwa hartamu dan anak-anakmu itu hanyalah sebagai cobaan dan sesungguhnya disisi Allahlah pahala yang besar.” (QS.al-Anfal ayat 28).

Ayat diatas, menjelaskan salah satu ujian yang diberikan Allah kepada sebagai orang tua adalah anak-anak mereka. Itulah sebabnya setiap orang tua hendaklah benar-benar bertanggung 
jawab terhadap amanah yang diberikan Allah Swt sekaligus sebagai ujian yang harus dijalankan. Jika anak yang di didik mengikuti ajaran Islam maka orang tua akan memperoleh ganjaran pahala yang besar dari hasil ketaatan mereka. Namun fakta yang ada masih banyak orang tua yang tidak bertanggung jawab terhadap anak-anaknya karena masih banyak anak-anak yang tidak memperoleh hak sepenuhnya dari orang tua mereka seperti hak mendapatkan perawatan dengan penuh kasih sayang, hak memperoleh pendidikan yang baik dan benar, hak menerima nafkah yang halal dan baik, dan memberikan pengasuhan sepenuhnya kepada orang lain karena kesibukan dan sebagainya. Kiranya, masalah itu bias di minimalisir dengan adanya pandemi Coronavirus ini, karena dengan adanya orang tua didekat anak lebih lama daripada sebelumnya. Orang tua akan focus dirumah dengan kelurganya, sehingga anak-anak mereka akan selalu diperhatikan.

Kedekatan anak dengan orang tua merupakan fondasi penting bagi tumbuh kembang anak. Kedekatan, kehangatan dan rasa cinta kasih orang tua dapat mencegah perilaku kenakalan dan depresi saat anak tumbuh dewasa. Kedekatan yang dijalin oleh orang tua kepada anak sejak dini juga akan berguna dalam pembentukan karakter anak. Kedekatan orang tua dan anak akan mempengaruhi kecerdasan anak. Interaksi orang tua dan anak sangat dibutuhkan, karena anak belajar dari berbagai macam interaksi yang dilakukannya dengan orang tua. Agar tujuan pengasuhan orang tua terhadap anak jelas tentu beberapa strategi yang harus dilakukan oleh orang tua dalam melakukan pengasuhan, terutama dalam mendukung kompetensi seorang anak, diantaranya adalah: Satu, keterlibatan orang tua dalam menyediakan kesempatan untuk menumbuhkan kompetensi pada anak. Dua, memberikan kesempatan untuk eksplorasi bebas dan pemberian tugas. Tiga, dipengaruhi oleh gaya pengasuhan orang tua. Empat, memberikan teladan perilaku. Lima, membentuk kelekatan emosi dan menciptakan keharmonisan keluarga. Enam, membimbing perilaku anak untuk mencapai tujuan hidupnya. Seorang anak akan mendapatkan pertumbuhan yang optimal jika terjalin hubungan dua arah dengan orang, benda, maupun simbol yang anak temukan pertama kali di lingkungan sekitarnya. Karena itu interaksi sangat penting untuk dilakukan secara berkesinambungan antara orang tua dan anak agar menjadi hubungan yang lebih kompleks dan akan menjadi stimulus dalam perkembangan seorang anak.

Pada masa pandemi Coronavirus seperti ini, salah satu pendidikan yang harus di berikan orang tua yaitu dengan mengajarkan betapa pentingnya menjaga kesehatan. Karena kesehatan merupakan kondisi dimana kita berada jauh atau terbebas dari penyakit. Merupakan suatu yang mahal jika dibandingkan dengan hal-hal yang lain. Kita semua mengetahui jika ada sehat dan ada sakit, kita tidak akan selalu sehat dan kita juga tidak akan selalu sakit. Semuanya itu bagaimana kita bisa menjaga diri untuk terhindar dari penyakit sehingga kesehatan itu merupakan hal yang mutlak harus dijaga (Anam, 2016, p. 97). Anak-anak harus diberi pengertian tentang hidup bersih dengan rajin mandi minimal 2 kali sehari pagi dan sore, rajin menggosok gigi setelah makan dan sebelum tidur. Membiasakan diri untuk membuang sampah pada tempatnya, berusaha untuk menjaga lingkungan sekitar baik di dalam rumah dan di luar rumah tetap bersih. Selain itu orang tua juga membiasakan diri anak untuk hidup sehat seperti makan makanan bergizi seperti buah-buahan bervitamin dan sayuran berserat. Melakukan olahraga bersama setiap pagi, memperbanyak minum air putih dan tidur secukupnya. Hal tersebut bisa terwujud dengan orang tua melakukan pembiasaan hidup bersih dan sehat di rumah tidak hanya memerintah anak untuk melakukannya tetapi orang tua juga ikut melakukan pembiasaan tersebut. Sehingga anak menirukan apa yang orang tuanya lakukan. Hal ini menjadi penting bagi anak untu hidup bersih dan sehat untuk mencegah anak tertular Coronavirus.

Membatasi pemakaian internet memang wajib dilakukan baik itu waktu maupun situs-situs yang dituju. Sepakati bersama berapa jam anak bermain internet dalam sehari, apa saja yang boleh diakses, juga membatasinya dengan aplikasi yang bisa menyaring situs-situs konten 
dewasa, kekerasan dan games tidak bermanfaat serta film yang tidak mendidik. Membentengi anak dengan agama memang sangat penting. Di jaman yang serba terbuka ini sudah tidak mungkin lagi mensterilkan anak dari internet. Berilah mereka iman, kekebalan untuk mampu menyeleksi sendiri apa yang baik untuk dirinya maupun yang tidak baik. Berilah pemahaman bahwa memang teknologi memudahkan tetapi agamalah yang akan menyelamatkan di dunia dan di akhirat. Jadikan pembelajaran keagamaan bukan sebatas doktrinasi dan hapalan, tapi sentuhlah emosinya hingga dia memahami, menyenangi bahkan merindukan ritual keagamaan, terlebih tentang kecintaan kepada Sang Pencipta, inilah peran utama bagi orang tua di zaman digital (Nurlina, 2019, pp. 549-559).

Persepsi orang tua dalam mewujudkan kepribadian dan pendidikan anak dan untuk memahami sebab orang tua harus lebih terlibat dalam pendidikan anak. Pendidikan yang diberikan oleh orang tua kepada anaknya adalah merupakan pendidikan yang akan selalu berjalan seiring dengan pembentukan kepribadian anak tersebut dan peran orang tua dalam menunjang pendidikan anak terbatas pada persoalan dana. Persepsi orang tua bertanggung jawab juga memikirkan dan mengusahakan agar senantiasa terciptakan dan terpelihara suatu hubungan antara orang tua dengan anak yang baik, efektif dan menambah kebaikan dan keharmonisan hidup dalam keluarga, sebab telah menjadi bahan kesadaran para orang tua bahwa hanya dengan hubungan yang baik kegiatan pendidikan dapat dilaksanakan dengan efektif dan dapat menunjang terciptanya kehidupan keluarga yang harmonis. Persepsi orang tua diharapkan dapat melakukan semua itu dengan niat yang tulus untuk menciptakan generasi yang mempunyai moral yang luhur dan wawasan yang tinggi serta semangat pantang menyerah dan sikap apatis orang tua yang peduli terhadap pendidikan anak akan menambah jumlah mutu pendidikan yang baik (Siregar, 2013, pp. 27-11).

\section{SIMPULAN DAN SARAN}

Masa pendemi Coronavirus memberikan banyak pelajaran bagi kita semua, terlebih bagi orang tua yang anaknya masih dalam jenjang pendidikan mulai dari tingkat terbawah Taman Kanak-kanak, Sekolah Dasar, Sekolah Menengah Pertama, Sekolah Menengah Atas, samapai tingkat universitas. Masa pandemi ini orang tua diharuskan untuk memperhatikan bagaimana proses pendidikan anaknya, yang mungkin sebelumnya orang tua hanya sibuk bekerja sehingga kurang memperhatikan pendidikan sang anak, sekarang harus menemani, membimbing dan mengawasi proses pendidikan anak mereka. Karena memang sudah tertulis di dalam Al-Qur'an dan Hadits bahwa pemberian pendidikan merupakan tanggung jawab orang tua, baik dalam pendidikan fisik, kecerdasan (kognitif) sampai pendididkan agama yang merupakan pokok dari pendidikan yang wajib harus orang tua berikan, bahkan sejak anak masih dalam kandungan orang tuanya.

Islam mengajarkan bagi pemeluknya untuk mengikuti apa yang telah menjadi pedoman guna menjalankan kehidupannya di dunia yang dapat mengantarkannya kepada tujuan akhir semua manusia yaitu menuju pencipta-Nya. Di masa pandemi Coronavirus ini orang tua sebaiknya menekankan pemberian pendidikan spiritual kepada anaknya, misalnya saja mengajak anak untuk rutin menjalankan ibadah sholat berjamaah, menjaga kebersihan dari segala aspek yaitu kebersihan badan dan kebersihan lingkungan sekitar. Terlebih lagi jika anak-anak masih dalam jenjang usia dini, pendidikan yang berkaitan dengan akidah keislaman, akhlak, kebiasaan yang baik akan lebih merasuk dalam diri anak, karena dari kecil anak-anak sudah diajarkan dan ditunjukkan bagaimana melakukan ibadahnya dengan benar, sehingga sampai anak dewasa nanti anak-anak tidak akan lupa bagaimana caranya. Selain itu masa ini membuat para orang tua harus ekstra berhati-hati dalam menjaga anak mereka, anak-anak harus selalu di beri pengertian apakah yang sedang terjadi disekitarnya. Ajak anak untuk selalu menjaga kebersihan, rajin mencuci 
tangan, dan beri pengertian kepada nak untuk bermain jauh-jauh dari tempat tinggal, karena memang masih belum dalam keadaan yang aman.

Masa pandemi Coronavirus ini membuat system pembelajaran di Indonesia dirubah yaitu dnegan system Daring. Pembelajaran yang anak-anak terima melalui system Daring (Dalam jaringan), memungkinkan anak berinteraksi dnegna telephone genggam lebih lama, sehingga orang tua harus benar-benar menajalankan tugasnya yaitu mendampingi anak dalam proses belajar sang anak. Dengan melihat oarantua yang selalu di samping anak, mereka akan lebih semangat dalam mengikut system belajar yang dilakukan dirumah. Kebosanan anak hilang jika mereka merasa diperhatikan oleh oramgtuanya. Namun menjadi sedikit masalah jika ada orang tua yang masih belum terlalu mengenal social media (Gaptek), banyak sekali masalah yang dikeluhkan oleh orang tua terkait proses pembelejarang yang dilakukan Daring tersebut. Namun Pemerintah akan secepatnya memberikan solusi untuk semua keluahan-keluhan dari masyarakat. Sehingga proses pendidikan akan terus berjalan dengan baik walaupun dengan situasi pada masa Pandemi Coronavirus seperti ini.

Berdasarkan kesimpulan diatas, maka dapat disampaikan saran bahwa orang tua senantiasa harus mendampingi anak-anaknya dalam proses pembelajaran daring ini. Orang tua tidak boleh panik dalam menghadapi pandemi Coronavirus ini, orang tua harus tenang dalam menghadapi segala segala keadaan anaknya. Orang tua harus siap menjadi sosok yang siap membantu dan menyiapkan tugas-tugas anak. Orang tua harus dewasa dalam menghadapi perubahan sikap anak. Kemampuan berkomunikasi dengan anak yang baik serta kemampuan dalam memilihkan aktivitas yang seimbang dan sesuai dengan perkembangan anakharus menjadi hal yang wajib dimiliki oleh orang tua. Masa pandemi Coronavirus bukan artinya anak berhenti belajar, mereka harus tetap melanjutkan pembelajaran dengan dukungan penuh dari sekolah dan orang tua. Masa pandemi ini bias menjadi kesempatan yang tepat orang tua untuk terlubat dalam proses pendidikan anak.

\section{AKNOWLEDGMENT}

Penelitian ini didukung oleh Universitas Islam Negeri Sunan Kalijaga Yogyakarta

\section{DAFTAR RUJUKAN}

Anam, Khairul. Pendidikan Perilaku Hidup dan Sehat Prespektif Islam. Jurnal Sagacious. Vol.3 No.1 Juli-Desember 2016.

Asadullah, M Niaz, and Nazmul Chaudhury. "To Madrasahs or Not to Madrasahs: The Question and Correlates of Enrolment in Islamic Schools in Bangladesh." International Journal of Educational Development $49 \quad$ (July $1, \quad$ 2016): $55-69$. https://doi.org/10.1016/j.ijedudev.2016.01.005.

Asqalany, al-, Ahmad ibn Ali ibn Hajar. (2005). Fath Al-Bary Bi Syarh Sahih al-Bukhari. Riyadh: Dar al-Taybah.

Ba, Harun Hasan. "Pendidikan Anak dalam Keluarga; Telaah Epistemologis Pedagogik". Jurnal Pendidikan, Vol. 3, No. 2 Januari-Juni 2016.

Cahyono, Guntur. Pendidikan Karakter Perspektif Al-Quran dan Hadits. Al-Astar: Jurnal Ahwal al-Syahsiyah dan Tarbiyah STAI Mempawah. Vol.V No.1 Maret 2017.

Daien Indra Kusuma, Amir. (1973). Pengantar Ilmu Pendidikan Sebuah Tinjauan Teoritis Filosofis. Surabaya: Usaha Nasioanal.

Elewa, A. "Authorship Verification of Disputed Hadiths in Sahih Al-Bukhari and Muslim." Digital Scholarship in the Humanities 34, no. 2 (2019): 261-76. https://doi.org/10.1093/1lc/fqy036. 
Fadhli, Muhibuddin. "Pemikiran Howard Gardner Dalam Pendidikan Anak Usia Dini." JURNAL INDRIA (Jurnal Ilmiah Pendidikan Prasekolah dan Sekolah Awal) 1, no. 1 (December 1, 2016). https://doi.org/10.24269/jin.v1n1.2016.pp69-80.

Filasofa, Lilif Muallifatul Khorida. "Analisis Semiotika Pendidikan Moral Anak Usia Dini Dalam Kitab Tarbiyat Al-Aulad Fi Al-Islam." Sawwa: Jurnal Studi Gender 12, no. 1 (July 6, 2017): 111-26. https://doi.org/10.21580/sa.v12i1.1471.

Fitri, Anggi. Pendidikan Karakter Prespektif Al-Quran dan Hadits. Ta'lim: Jurnal Studi Pendidikan Islam. Vol.1 No.2 Juli, 2018.

Hari Wahyudi, Hendra. (2020). Pandemi COVID-19: Mengajak Orang tua Menjadi Guru, 29 Maret.

Hasbiyallah, Hasbiyallah. "Relevansi Materi Hadis Pada Jurusan Pai Dengan Bahan Ajar Quran Hadis Pada Madrasah Tsanawiyah." Atthulab: Islamic Religion Teaching and Learning Journal 1, no. 1 (February 17, 2016): 71-84. https://doi.org/10.15575/ath.v1i1.2436.

Hidayati, Laily. "Qashashul Quran: Pengembangan Mata Kuliah Wajib Program Studi Pendidikan Islam Anak Usia Dini (PIAUD).” Proceedings of Annual Conference for Muslim Scholars, no. Seri 2 (May 14, 2017): 909-19.

Indriyati, Anisa. "Pendidikan Anak Dalam Keluarga Sebagai Bentuk Perlindungan Anak Dalam Perspektif Al-Qur'an". UIN Sunan Kalijaga Yogyakarta: Musawa, Vol. 10, No. 2, Juli 2011.

Joesoef, Soelaiman. (1992). Konsep Dasar Pendidikan Luar Sekolah. Jakarta: Bumi Aksara.

Kementerian Pemberdayaan Perempuan dan Perlindungan Anak. (2020). Buku Aktivitas: Gembira Bersama Abi dan Ummi.

Kusuma, Amir Daien Indra. (1973). Pengantar Ilmu Pendidikan Sebuah Tinjauan Teoritis Filosofis. Surabaya: Usaha Nasioanal.

Masitoh, Imas. "Analisis Faktor-Faktor Yang Mempengaruhi Mahasiswa Memilih Program Studi (Prodi) PIAUD Di STIT NU al-Farabi Pangandaran.” Jurnal Pendidikan Islam AlIlmi 1, no. 1 (May 31, 2018). https://doi.org/10.32529/al-ilmi.v1i1.336.

Mahdi M. Ali, Pembelajaran Pendidikan Agama Islam Bagi Anak Usia Dini, Jurnal Edukasi Vol 1 Nomor 2 (July 2015).

Muhammad Hanif Alathas, Habib. (2020). Menyikapi Corona: Antara Aqidah, Fiqih dan Adab. Sabtu, 21 Maret 2020, 14:18.

Mulyani, R, Meningkatkan kemampuan Interaksi Sosial pada Anak dengan Social Skill Training. Procedia Studi Kasus dan Intervensi Psikologi, Volume 1 (1), 07-11, 2013

Mulyasa. (2014). Manajemen PAUD. Bandung: PT. Remaja Rosdakarya.

Nur Ichwan Muslim, Muhammad. (2014). Pendidikan Anak, Tanggung Jawab Siapa? 17 Maret 2014.

Nurlina, "Peran Orang Tua dalam Pembentukan Kepribadian Anak di Era Digital". An Nisa' Jurnal Studi Gender dan Anak 2019, Vol. 12, No. 1, 549-559 ; Terbit di http://jurnal.iainbone.ac.id/index.php/annisa.

Purnomo, Agus. "Pendidikan Anak Dini Usia (PAADU) Dalam Islam: Sebuah Analisis Gender." EGALITA 0, no. 0 (May 12, 2012). https://doi.org/10.18860/egalita.v0i0.1965.

Putra, Ary Antony. Konsep Pendidikan Agama Islam Perspektif Imam Al-Ghazali, Jurnal AlThariqah, Vol. 1 No.1 (Juni 2016).

Puspitaloka, Nina, and Yuna Tresna Wahyuna. "Kesulitan-Kesulitan Yang Dihadapi Mahasiswa PIAUD Dalam Pembelajaran Bahasa Inggris.” AWLADY : Jurnal Pendidikan Anak 4, no. 2 (September 30, 2018): 120-36. https://doi.org/10.24235/awlady.v4i2.3071.

R, Mulyani. Meningkatkan kemampuan Interaksi Sosial pada Anak dengan Social Skill Training.Procedia Studi Kasus dan Intervensi Psikologi, Volume 1 (1), 07-11, 2013. 
Retnaningrum, Wulandari. (2018). Pendidikan Karakter Bagi Anak Usia Dini Perspektif Islam." Jurnal Warna 2, no. 2, pp. 56-68.

Roziqoh, Roziqoh, and Suparno Suparno. "Pendidikan Berperspektif Gender Pada Anak Usia Dini." JPPM (Jurnal Pendidikan Dan Pemberdayaan Masyarakat) 1, no. 1 (March 1, 2014): 86-100. https://doi.org/10.21831/jppm.v1i1.2359.

Setiawati dan Suparno. "Interaksi sosial dengan Teman Sebaya pada Anak Homeschooling dan Anak seklah Reguler", Jurnal Ilmiah Berkala Psikologi, Vol.12. 2010.

Sidiq Umar. Urgensi Pendidikan Pada Anak Usia Dini. Jurnal Insania, Vol. 16 No.2 (MeiAgustus 2011)

Sulaemang, Sulaemang L. "Teknik Interpretasi Hadis Dalam Kitab Syarah Al-Hadis." Jurnal Ilmiah Ilmu Ushuluddin 14, no. 2 (March 7, 2016): 125-32. https://doi.org/10.18592/jiu.v14i2.697.

Soelaiman, Joesoef. (1992). Konsep Dasar Pendidikan Luar Sekolah. Jakarta: Bumi Aksara.

Tim, CNN Indonesia, Mengenal Makna Status Pandemi Virus Corona, Kamis, 12/03/2020 12:29

Ulwan, Abdullah Nasih. (2001). Pendidikan Anak Dalam Islam. Jakarta: Pustaka Amani.

Umar, Munirwan. "Peranan Orang Tua Dalam Peningkatan Prestasi Belajar Anak". Jurnal Ilmiah Edukasi Vol 1, Nomor 1, Juni 2015

Yahya, Agusni. "Pendekatan Hermeneutika Dalam Pemahaman Hadis: Kajian Kitab Fath al-Bari Karya Ibn Hajar al-Asqalany." Ar-Raniry International Journal of Islamic Studies, Vol. No. 2 Desember 2014, 365-86.

Yaqin, Ainul. "Problematika Pembelajaran Al-Qur'an Hadis Di Madrasah Tsanawiyah Negeri (MTs.N) 1 Kolaka." Jurnal Kariman 2, no. 1 (2014) pp. 69-84.

Zulfitria. Pola Asuh Orang Tua dalam Pendidikan Karakter Berbasis Al-Quran untuk Anak Usia Dini. Yaa Bunayya: Jurnal Pendidikan Anak Usia Dini. Vol.1 No.2 November 2017

\section{AUTHOR}

Afifah Fatihakun Ni'mah Wahidah Lahir : Ngawi, 25 Juni 1996 alumni UIN Sunan Kalijaga Yogyakarta (2015-2019), dan sedang menempuh program Magister PIAUD di UIN Sunan Kalijaga Yogyakarta

Dr. H. Muhammad Alfatih Suryadilaga, S.Ag. M.Ag. merupakan Asosiate Profesor dalam Matakuliah Hadits di Prodi Ilmu Hadits Fakultas Ushuluddin dan Pemikiran Islam UIN Sunan Kalijaga Yogyakarta. Sekarang menjabat sebagai Kaprodi Ilmu Hadits dan ketua Asosiasi Ilmu Hadits Indonesia (ASILHA). Selain itu, sebagai ketua Yayasan Pondok Pesantren al-Amin Lamongan Jawa Timur. Karya tulisan bias dilihat di https://scholar.google.co.id/citations? 